\title{
The relationship between the Municipal Human Development Index and rates of violent death in Brazilian Federal Units
}

\author{
Lylla Winzer, PhD*
}

DOI: http://dx.doi.org/10.7322/jhgd.119275

\begin{abstract}
Because countries with the highest Human Development Index (HDI) have low rates of violence, it is common to assume that the increase of HDI may correspond with lower rates of violence in a country. This study examined the relationship between the Municipal Human Development Index (MHDI) and violent deaths in the Brazilian States between 1991 and 2010. We tested whether the increase of MHDI indirectly reduces violence or whether the reduction of violence predicts higher MHDI in later years. The raw data were obtained from three sources online, Atlasbrasil, IPEAdata and Map of violence. The analyses do not support the assumption that the increase of MHDI leads to a reduced level of violence. However, there are indications that the decrease of homicides over the years results in improved MHDI rates in 2010. The results suggest that taking measures aimed at development does not automatically imply a lower level of violence, but fighting against violence may increase MHDI.
\end{abstract}

Key words: violence, human development index, inequality, Brazil.

\section{INTRODUCTION}

The Human Development Index (HDI) is measured from three indicators, namely, education, longevity and income. It is a useful measure because it enables us to assess whether economic growth translates into a better well-being and quality of life for the population. It also has the advantage of allowing comparisons among different countries. Because countries with the highest HDI have lower rates of violence, it is common to assume that the increase of HDI may represent, in the long term, a reduction in violence ${ }^{1}$. There is also the hypothesis that the rise of HDI over the years may represent a decrease in homicide rates and an increase in suicides². This thesis is based on data from countries with very high degrees of HDI, such as Japan and Norway, in which despite their low rates of violence, they present high rates of suicide.

However, there seems to be no studies that empirically test whether hetero-directed violence decreases and self-directed violence increases with the growth of HDI. In Brazil, there are a limited number of statistical studies that evaluate the relationship between HDI and violent deaths (due to homicide, suicide and traffic accidents). Only one Brazilian study was identified on this issue and found a negative association between homicide rates and MHDI (Municipal Human Development Index) ${ }^{3}$. However, that study was cross-sectional (data were from the year 2000) and included the analysis of only four cities in Mato Grosso do Sul State, offering little insight into the variation of this association over time and in the country as a whole.

Although it is agreed that there is a relationship between violence and HDI, the direction of this association is not clear. Although many authors defend the hypothesis that the increase in HDI (mainly concerning increases in income and education) may represent, in the long term, a reduction of violence, the United Nations Development Programme (UNDP) argues that HDI grows despite violence, but violence might curb the growth of HDI. A proof of this is that even with increasing HDI in Latin America, the population still lives under the threat of a violence epidemic ${ }^{4}$.

The effect of HDI on violence rates, or vice versa, is of particular relevance to public policy. What can be empirically validated from Brazilian data: the increase in HDI indirectly reducing violence over the years? Or the reduction of violence predicting higher values of HDI in later years?

\footnotetext{
* Institute for Population and Social Research Mahidol University - Salaya, Phutthamonthon, Nakhon Pathom - 73170, Thailand

Corresponding author: Lylla Winzer, PhD.- E-mail: lylla.winzer@yahoo.com ou lylla.win@mahidol.ac.th
}

Suggested citation: Winzer L. The relationship between the Municipal Human Development Index and rates of violent death in Brazilian Federal Units. J Hum Growth Dev. 26(2): 211-217. Doi: http://dx.doi.org/10.7322/jhgd.119275.

Manuscript submitted: Apr 16 2016, accepted for publication Apr 212016. 


\section{The challenges of assessing the Municipal Human Development Index and Violence}

Brazilian researchers faced two challenges regarding the measurement of HDI. The first was how to identify the Human Development Index for States and Municipalities separately. The second was how to compare rates over the years, since calculations made in previous decades differed from how the index is calculated today. In response to these challenges, the Atlas of Human Development in Brazil ${ }^{5}$ has recently released a new database with the so-called MHDI (Municipal Human Development Index), which is an adaptation of the Global HDI methodology for calculating the HDI of States and Municipalities for the years 1991, 2000 and 2010. In addition, the new database has been updated so that rates from previous years (1991 and 2000) have been recalculated in accordance with the current methodology, making the data comparable over the years.

Data on violence in Brazil represent an even greater challenge to researchers. It is known that most crimes are not reported to the police. When they are reported, only a portion enters the official statistics. This happens for a number of reasons such as failures in the registry and flow of information by Municipalities. Another problem refers to the comparison of crime records over the years: the increase or decrease of rates from one year to another does not necessarily manifest a real change in the incidence of crime. This variation may only indicate a difference in the number of reported crimes or an adjustment in the methods applied by official agencies in order to collect data. For example, higher rates in a year, compared to previous years, may indicate greater awareness of the importance of crime reporting. On the other hand, a decrease in crime rates might signify that violence is so trivialized that, due to disbelief on the work of the police, fewer people may ask for help.

In order to obtain more reliable data, the term 'violence' can be operationalized based on the number of violent deaths (i.e., homicides, traffic deaths and suicide) 6; 7, even if this represents explicitly a reductionism. Violence is a broad concept and includes phenomena such as child abuse and neglect, juvenile delinquency, intimate partner violence, sexual violence, violence against the elderly and collective violence ${ }^{8}$. However, many experts see advantage in the use of the number of violent deaths for three main reasons. First, the term is less ambiguous and less likely to be biased in comparison to other types of crime. Second, the victims of violent deaths are identified by different agencies (hospitals and Institutes of Legal Medicine), and not only by the police. Third, death registration certificate is mandatory for any burial, ensuring more realistic data ${ }^{6 ; 7}$. Although hetero-directed violence may have different dynamics compared to selfdirected violence (suicide) with respect to HDI, both are grouped here under the same nomenclature "violent deaths" as a general indicator of violence for each of the twenty seven Brazilian Federal Units.
Thus, the aim of the present study is to analyze the relationship between the Municipal Human Development Index and violent death rates in Brazilian Federal Units. Because previous studies have shown that inequality ${ }^{9}$ and poverty $^{8}$ act as risk factors for violence, further analysis will be conducted on the association between violent deaths, GINI coefficient and the proportion of poor (PMPOB) and extremely poor (PIND) people.

\section{METHODS}

This is a retrospective longitudinal study based on secondary data from three online sources: Atlasbrasil ${ }^{5}$, IPEAdata $^{10}$ and Map of Violence ${ }^{11,12}$. From each source, the following variables were obtained:

1) Atlasbrasil ${ }^{5}$ : Municipal Human Development Index (MHDI), inequality coefficient (GINI), the proportion of individuals with per capita household income equal to or less than 140 Brazilian Real a month (This is called by Atlasbrasil as 'proportion of poor people' and its acronym is PMPOB) and the proportion of individuals with per capita household income equal to or less than 70 Brazilian Real a month ('proportion of extremely poor people'; PIND);

2) IPEAdata ${ }^{10}$ : rates of homicide, suicide and traffic deaths per 100,000 inhabitants for the years 1991, 2000 and 2009*;

3) Map of Violence 2013: rates of homicides ${ }^{11}$ and deaths in traffic accidents ${ }^{12}$ per 100,000 inhabitants for the year 2010.

Excel tables provided by Atlasbrasil and IPEAdata were exported and analyzed in SPSS and Mplus statistical programs. Data obtained from the report Map of Violence 2013 were manually transferred to the same programs for analysis.

\section{RESULTS}

The descriptive analysis of the data (Table 1) shows that between 1991 and 2010 there was an average increase of MHDI, accompanied by an increase in the number of casualties in traffic accidents, homicide and suicide. In the same period, there were also, on average, a decrease in inequality and the proportion of poor and extremely poor people in the Brazilian Federal Units.

The correlation coefficients among the variables studied (Table 2) show that the association between human development indexes and traffic accidents deaths, homicide and suicide varies by year. For example, the correlation between MHDI and homicide rates changes from positive to negative from 1991 and 2000 to 2009/10. However, this does not happen to the association between MHDI and traffic deaths and suicide. In this case, the correlation becomes less robust and non-significant in 2009/10, but it still remains positive. Suicide rates in 2009 continue to achieve significance when correlated with the

* There are no data available on IPEAdata on homicides, suicides and traffic fatalities for the year 2010. 
Table 1: Mean values of Municipal Human Development Index (and its three corresponding indicators: education, longevity and income), inequality, the proportion of poor and extremely poor people and violent death rates (due to traffic accidents, homicide and suicide per 100,000 inhabitants) in the Brazilian Federal Units for the years 1991, 2000, 2009 and 2010

\begin{tabular}{lccccc} 
& \multicolumn{5}{c}{ Mean (SD) } \\
& $\mathbf{1 9 9 1}$ & $\mathbf{2 0 0 0}$ & $\mathbf{2 0 0 9}$ & $\mathbf{2 0 1 0}$ & $\Delta \%$ \\
$\mathrm{MHDI}^{1}$ & $.45(.07)$ & $.57(.07)$ & - & $.70(.04)$ & $\uparrow$ \\
$\mathrm{MHDI}$ Education & $.24(.07)$ & $.41(.09)$ & - & $.61(.05)$ & $\uparrow$ \\
MHDI Longevity & $.64(.06)$ & $.72(.04)$ & - & $.80(.03)$ & $\uparrow$ \\
MHDI Income & $.59(.06)$ & $.64(.06)$ & - & $.70(.05)$ & $\uparrow$ \\
$\mathrm{GINI}^{2}$ & $.61(.02)$ & $.62(.03)$ & - & $.59(.03)$ & $\downarrow$ \\
PMPOB $^{3}$ & $45.8(17.9)$ & $35.2(16.3)$ & - & $19.9(11.5)$ & $\downarrow$ \\
PIND $^{4}$ & $23.4(13.2)$ & $16.7(10.6)$ & - & $9.3(6.6)$ & $\downarrow$ \\
Traffic deaths & $19.1(8.2)$ & $20.3(7.7)$ & $22.8(7.4)$ & $25.8(7.4)$ & $\uparrow$ \\
Homicides & $20.7(11.6)$ & $24.6(14.2)$ & $30.1(11.4)$ & $31.6(12.0)$ & $\uparrow$ \\
Suicides & $3.5(2.2)$ & $4.2(2.3)$ & $5.1(2.0)$ & - & $\uparrow$ \\
\hline
\end{tabular}

Note. 1 Municipal Human Development Index; 2 Gini coefficient; 3 Proportion of poor people; 4 Proportion of extremely poor people; $\uparrow$ increase; $\downarrow$ decrease.

Table 2: Correlation of Municipal Human Development Index, inequality, proportion of poor and extremely poor people with violent deaths rates (due to traffic accidents, homicides and suicides per 100,000 inhabitants) for the years 1991, 2000, 2009 and 2010

\begin{tabular}{|c|c|c|c|c|c|c|c|c|c|c|c|c|}
\hline \multirow[t]{2}{*}{ Year } & \multirow[b]{2}{*}{ Indicators } & \multirow[b]{2}{*}{ Traffic } & \multirow{2}{*}{$\begin{array}{c}1991 \\
\text { Homicides }\end{array}$} & \multirow[b]{2}{*}{ Suicide } & \multirow[b]{2}{*}{ Traffic } & \multirow{2}{*}{$\begin{array}{c}2000 \\
\text { Homicides }\end{array}$} & \multirow[b]{2}{*}{ Suicide } & \multirow[b]{2}{*}{ Traffic } & \multirow{2}{*}{$\begin{array}{c}2009 \\
\text { Homicides }\end{array}$} & \multirow[b]{2}{*}{ Suicide } & \multicolumn{2}{|c|}{2010} \\
\hline & & & & & & & & & & & Traffic & Homicides \\
\hline \multirow{7}{*}{1991} & $\mathrm{MHDI}^{1}$ & $.75^{* *}$ & $.39^{*}$ & $.66^{* *}$ & & & & & & & & \\
\hline & MHDIE & $.75^{* *}$ & .38 & $.60^{* *}$ & & & & & & & & \\
\hline & 'MHDIL & $.64^{* *}$ & .27 & $.67^{* *}$ & & & & & & & & \\
\hline & MHDIR & $.71^{* *}$ & $.49^{*}$ & $.66^{* \star}$ & & & & & & & & \\
\hline & $\left.\mathrm{GIN|}\right|^{2}$ & $-.56^{\star *}$ & -.10 & $-.47^{*}$ & & & & & & & & \\
\hline & $\mathrm{PMPOB}^{3}$ & $-.72^{\star *}$ & $-.43^{*}$ & $-.67^{\star \star}$ & & & & & & & & \\
\hline & $\mathrm{PIND}^{4}$ & $-.73^{* *}$ & $-.43^{*}$ & $-.64^{* *}$ & & & & & & & & \\
\hline \multirow{7}{*}{2000} & $\mathrm{MHDI}^{1}$ & & & & $.45^{*}$ & $.42^{*}$ & $.57^{* *}$ & & & & & \\
\hline & MHDIE & & & & $.44^{*}$ & $.42^{*}$ & $.52^{* *}$ & & & & & \\
\hline & MHDIL & & & & $.39^{*}$ & .26 & $.64^{* *}$ & & & & & \\
\hline & MHDIR & & & & $.45^{*}$ & $.49^{* *}$ & $.57^{\star *}$ & & & & & \\
\hline & $\left.\mathrm{GIN|}\right|^{2}$ & & & & $-.41^{*}$ & -.21 & $-.65^{\star *}$ & & & & & \\
\hline & $\mathrm{PMPOB}^{3}$ & & & & $-.48^{*}$ & $-.44^{*}$ & $-.65^{\star *}$ & & & & & \\
\hline & $\mathrm{PIND}^{4}$ & & & & $-.49^{*}$ & $-.45^{*}$ & $-.65^{\star \star}$ & & & & & \\
\hline \multirow{7}{*}{2010} & $\mathrm{MHDI}^{1}$ & & & & & & & .18 & -.18 & .36 & .14 & -.32 \\
\hline & MHDIE & & & & & & & .19 & -.25 & .34 & .14 & -.37 \\
\hline & MHDIL & & & & & & & .16 & -.18 & $.42^{*}$ & .10 & -.32 \\
\hline & MHDIR & & & & & & & .17 & -.04 & .34 & .13 & -.23 \\
\hline & $\left.\mathrm{GIN}\right|^{2}$ & & & & & & & $-.48^{*}$ & .24 & $-.52^{* \star}$ & $-.41^{*}$ & .34 \\
\hline & $\mathrm{PMPOB}^{3}$ & & & & & & & -.31 & .12 & $-.42^{*}$ & -.27 & .27 \\
\hline & $\mathrm{PIND}^{4}$ & & & & & & & -.29 & .045 & -.37 & -.25 & .19 \\
\hline
\end{tabular}

Note: **. Correlation is significant at the 0.01 level (bilateral); ${ }^{*}$. Correlation is significant at the 0.05 level (bilateral); 1 Human Development Index (education, longevity and income); 2 Gini coefficient; 3 Proportion of poor people; 4 Proportion of extremely poor people.

MHDI indicator for longevity (MHDIL) in 2010. Unlike homicide rates, traffic deaths and suicide also present significant negative correlation with inequality (GINI) between the years 1991 and 2009/10. Suicide rates also remain in 2009 significantly negatively correlated with the number of poor people.

To understand the variation of development indexes according to violent deaths over time (and not just in one year), it was investigated whether the increase or decrease of development indexes between 1991 and 2010 correlates with an increase or decrease of violent deaths in the same period. Table 3 shows the association between variation of MHDI, GINI, PMPOB, and PIND between 1991 and 2010 with the variation in rates of violent deaths between 1991 and 2009/10. That is, the Table 3 does not refer to the correlation among raw data, but among the trends of increase or decrease of these variables over the period considered. The results show, for example, that an increase in MHDI between the years 1991-2010 is positively related to an increase in homicides, traffic deaths and suicide, but there was statistical significance only with the last two variables. The same table also indicates that, on average, the reduction in the number of poor and extremely poor people are significantly correlated with an increase in the number of violent deaths in the same period. These data must, however, be considered with caution: first, they do not imply causality, and second, they disregard differences among the States (see Table 4).

To understand the trends of increase or decrease of MHDI and violent deaths for each of the twenty seven Brazilian Federal Units, Table 4 describes how these rates changed over the period of 1991-2009/10. The results show that development indexes and violent deaths vary greatly among the Federal Units, indicating how 
Table 3: Correlation between the difference ${ }^{+}$between 1991 and 2009/10 of MHDI, GINI, PMPOB, PIND, traffic deaths, homicides and suicide rates in all Brazilian Federal Units.

\begin{tabular}{|c|c|c|c|c|c|c|c|}
\hline & (1) & $(2)$ & (3) & (4) & (5) & $(6)$ & (7) \\
\hline (1) MHDI 1991-2010 & 1 & & & & & & \\
\hline (2) GINI 1991-2010 & -.18 & 1 & & & & & \\
\hline (3) PMPOB 1991-2010 & $-.73^{* *}$ & $.48^{*}$ & 1 & & & & \\
\hline (4) PIND 1991-2010 & $-.73^{* *}$ & .26 & $.94^{* *}$ & 1 & & & \\
\hline (5) Traffic 1991-2010 & $.82^{* *}$ & -.40 & $-.67^{* *}$ & $-.62^{* *}$ & 1 & & \\
\hline (6) Homicides 1991-2010 & .38 & -.04 & $-.49^{* *}$ & $-.49^{* *}$ & .13 & 1 & \\
\hline (7) Suicide 1991-2009 & $.64^{* *}$ & -.28 & $-.56^{* *}$ & $-.50^{\star *}$ & $.69^{* *}$ & .24 & 1 \\
\hline
\end{tabular}

Note. ${ }^{* *}$. Correlation is significant at the 0.01 level (bilateral); ${ }^{*}$. Correlation is significant at the 0.05 level (bilateral); ${ }^{+}$the difference was calculated by subtracting the values of 1991 from the values obtained in 2010 (for HDI, GINI, PMPOB, PIND, traffic deaths and homicide) and in 2009 (for suicide rates). That is, positive values in the subtraction mean increasing rates from 1991 to 2009/2010, and negative values mean decreasing rates, that is, values in 2009/2010 were lower than 1991.

Table 4: Difference between 1991 and 2009/10 of MHDI, GINI, PMPOB, PIND, traffic deaths, homicides and suicide rates in Brazilian Federal Units.

\begin{tabular}{|c|c|c|c|c|c|c|c|}
\hline & $\begin{array}{c}\text { MHDI } \\
1991-2010\end{array}$ & $\begin{array}{c}\text { GINI } \\
1991-2010\end{array}$ & $\begin{array}{c}\text { PMPOB } \\
1991-2010\end{array}$ & $\begin{array}{c}\Delta \\
\text { PIND } \\
1991-2010\end{array}$ & $\begin{array}{c}\text { Traffic } \\
1991-2010\end{array}$ & $\begin{array}{l}\text { Homicides } \\
1991-2010\end{array}$ & $\begin{array}{c}\text { Suicide } \\
1991-2009\end{array}$ \\
\hline Rondônia & .28 & -.06 & -33.4 & -18.8 & 19.1 & -7.8 & 1.6 \\
\hline Acre & .26 & .00 & -23.1 & -12.8 & 5.6 & -1.8 & .4 \\
\hline Amazonas & .24 & .03 & -14.2 & -6.5 & 1.3 & 12.4 & 2.9 \\
\hline Roraima & .25 & .00 & -10.1 & -4.8 & 11.3 & -7.4 & -.9 \\
\hline Pará & .23 & .00 & -21.5 & -10.5 & 5.6 & 31.1 & .3 \\
\hline Amapá & .24 & .02 & -12.4 & -5.2 & -9.5 & 22.2 & .7 \\
\hline Tocantins & .33 & -.03 & -36.9 & -21.7 & 27.4 & 13.4 & 4.7 \\
\hline Maranhão & .28 & .02 & -33.7 & -23.1 & 10.9 & 14.0 & 1.4 \\
\hline Piauí & .28 & -.03 & -39.1 & -29.1 & 25.6 & 9.5 & 5.3 \\
\hline Ceará & .28 & -.05 & -36.0 & -25.1 & 12.8 & 22.2 & 3.8 \\
\hline Rio Grande do Norte & .26 & -.03 & -36.3 & -22.8 & 1.8 & 16.9 & 1.6 \\
\hline Paraíba & .28 & -.03 & -39.4 & -27.8 & 8.5 & 26.4 & 2.1 \\
\hline Pernambuco & .23 & -.03 & -30.8 & -19.3 & 5.8 & .7 & .5 \\
\hline Alagoas & .26 & .00 & -30.9 & -20.0 & 3.8 & 40.0 & 1.9 \\
\hline Sergipe & .26 & -.01 & -31.5 & -19.3 & 9.4 & 12.4 & 2.9 \\
\hline Bahia & .27 & -.05 & -36.5 & -25.2 & 13.0 & 35.5 & 1.7 \\
\hline Minas Gerais & .25 & -.05 & -30.0 & -14.4 & 7.5 & 10.7 & 2.4 \\
\hline Espírito Santo & .24 & -.04 & -29.8 & -13.7 & 3.6 & 14.1 & .04 \\
\hline Rio de Janeiro & .19 & -.02 & -15.7 & -5.3 & -3.5 & -6.2 & -.3 \\
\hline São Paulo & .21 & .01 & -6.4 & -1.5 & -6.7 & -16.5 & .4 \\
\hline Paraná & .24 & -.07 & -26.1 & -10.6 & 5.2 & 19.8 & .5 \\
\hline Santa Catarina & .23 & -.06 & -21.7 & -8.3 & -.76 & 5.4 & 1.0 \\
\hline Rio Grande do Sul & .20 & -.05 & -20.5 & -7.9 & 2.9 & .8 & 1.6 \\
\hline Mato Grosso do Sul & .24 & -.04 & -23.5 & -7.4 & 7.0 & 4.7 & 5.0 \\
\hline Mato Grosso & .28 & -.05 & -25.0 & -9.3 & 24.0 & 10.4 & 3.7 \\
\hline Goiás & .25 & -.04 & -24.7 & -8.5 & 1.8 & 11.8 & .8 \\
\hline Distrito Federal & .21 & .01 & -10.0 & -2.8 & -14.1 & 1.1 & -1.7 \\
\hline
\end{tabular}

Note. Positive sign means increasing values in the analyzed period (1991-2010 or 1991-2009). Negative sign means decreasing rates for the same period of analysis.

complex the relationship between MHDI and violence can be. MHDI grew in all Federal Units, however, five states showed an increase in the GINI, which means an increase in inequality. Despite better development indexes in the majority of the twenty seven Federal Units, in only five (18\%) States the number of homicides declined (Rondônia, Acre, Roraima, Rio de Janeiro and São Paulo), in nine (33\%) the number of deaths in traffic accidents decreased (Amapá, Rio Grande do Norte, Alagoas, Espírito Santo, Rio de Janeiro, São Paulo, Santa Catarina, Goiás and the Federal District) and in three (11\%) suicide rates diminished (Roraima, Rio de Janeiro and the Federal District). Interestingly, states with similar increase of MHDI, such as Rondônia and Paraíba, had, respectively, a decrease (-7.8) and an increase (26.4) in homicide rates. On the other hand, Federal Units with lower growth of MHDI in the same period, such as São Paulo and Rio de Janeiro, had an important decrease in the number of homicides.

The abovementioned analysis does not, however, indicate the direction of influence of one variable on another. Regression analyzes were conducted in order to simulate the effects of MHDI on rates of violent death, and vice versa. 
First, we tested the effect of variation of MHDI, GINI and PMPOB between the years 1991 until 2010 on homicide rates in 2010 (Hypothesis 1). The results showed that the increase of MHDI and decrease of GINI and PMPOB between 1991 and 2010 were not able to predict the number of homicides in $2010, \mathrm{R}^{2}=.98$, $\mathrm{F}(3,23)=.832, \mathrm{p}=.49$. However, the increase of MHDI and decrease of GINI and PMPOB between 1991 and 2010 were able to predict an increase in the number of traffic fatalities (Hypothesis 2), $\mathrm{R}^{2}=.527, \mathrm{~F}(3,23)=8,539, \mathrm{p}<.001$.

To investigate the inverse relationship, that is, the influence of variation of violent deaths on MHDI, a regression analysis was conducted by testing the effect of the variation in violent deaths between 1991 and 2009 (homicide, suicide and traffic deaths) on the value of MHDI in 2010 in the Federal Units (Hypothesis 3). The results showed that an increase in homicide rates, but not in suicide and traffic deaths, predicted significantly lower MHDI in 2010 (Table 5). In other words, a greater reduction of homicides between 1991 and 2009 predicted higher rates of MHDI in 2010. This model also predicted a significant proportion of the variance of MHDI in $2010, \mathrm{R}^{2}=.39, \mathrm{~F}(3,23)=4.94, \mathrm{p}<.01$. There was no evidence of multi-collinearity among the independent variables in the regression analyzes.

Table 5: Regression analysis: effect of the variation of violent deaths between 1991 and 2009 on the value of MHDI in 2010 in Brazilian Federal Units

\begin{tabular}{|c|c|c|c|c|c|c|}
\hline & \multirow[t]{2}{*}{$\mathrm{B}$} & \multirow[t]{2}{*}{ Standard Deviation } & \multirow[t]{2}{*}{$\beta$} & \multirow[t]{2}{*}{$p$} & \multicolumn{2}{|c|}{ Collinearity } \\
\hline & & & & & Tolerance & VIF \\
\hline (Constant) & .73 & .012 & & .00 & & \\
\hline Traffic deaths 1991-2010 & -.002 & .001 & -.45 & .07 & .48 & 2.082 \\
\hline Homicides 1991-2010 & -.002 & .001 & -.41 & .02 & .93 & 1.073 \\
\hline Suicide1991-2009 & .001 & .007 & .04 & .87 & .46 & 2.181 \\
\hline
\end{tabular}

\section{DISCUSSION}

This study investigated the relationship between development indexes (MHDI, GINI, PMPOB, and PIND) and violent deaths (due to traffic accidents, homicide and suicide per 100,000 inhabitants) in Brazilian States between 1991 and 2009/10. Using descriptive and inferential statistics, two main research questions were tested: 1) if the improvement of social indicators represents, in the long term, a reduction in violence level; or 2) if violence is responsible for lower development indexes over the years.

The results showed that, in a general way, Brazilian States showed improvements in their development indexes with an increasing human development and simultaneous reduction of inequality and number of poor and extremely poor people between 1991 and 2010. The correlation of these indices with violent deaths, however, varies according to the decade, indicating that the relationship between human development and violence is complex and influenced by the time. This is evident when analyzing this relationship for each of the twenty seven Brazilian Federal Units separately, in which it becomes clear the limitations of models that propose a direct relationship between MHDI, GINI and violence: for example, the assumption that increasing MHDI means reducing violence.

Regression analysis indicate that increasing MHDI and decreasing GINI and PMPOB did not imply lower homicide or suicide rates, but are able to predict higher number of traffic deaths. This can be explained by the fact that an increase in income of the poorest population has led to a boost in the number of motorcycles in Brazil and, consequently, an alarming augmentation in the number of traffic accidents involving motorcyclists ${ }^{12}$.

Contrary to what is often suggested in the literature, these data reject the hypothesis that development implies decrease of violent deaths ${ }^{1}$. At least in Brazil, this assumption does not seem to be true. Correlation data also do not seem to confirm the thesis that the increase of MHDI reflects a decrease in hetero-directed violence and an increase in self-directed violence ${ }^{2}$. Moreover, although suicide, homicide and deaths in traffic accidents are often grouped as "violent deaths" as a general indicator of violence, the three phenomena seem to have different dynamics with respect to human and economic development.

Regression analyzes also suggest that the reduction in homicide rates in the last two decades contributes to better MHDI in 2010. Identifying the direction of the effect of one variable to another is of particular importance for public policy. Assuming that development and economic growth will directly reduce violence can be a fallacy. Measures against violence cannot be taken indirectly (e.g., through economic growth and reduction of social inequality), since they do not seem to be sufficient to stop violence. Instead, the violence epidemic in Brazil should be treated directly with measures that have been empirically tested as effective in the long term, such as, improving the quality of official data, strengthening the police force, reinforcing solidarity among community members, reducing intrafamilial violence, regenerating damaged public spaces, establishing a culture of nonviolence and peace, providing services to youths at risk, supporting community responses to urban violence, treating violence as a public health problem, teaching in schools strategies of conflict resolution, banning 
firearms and corporal punishment and promoting social responsibility on television ${ }^{6 ; 13}$.

Violence is a major obstacle to the growth of MHDI in Brazil. Future research should empirically investigate possible mediating variables that explain mechanisms of how violence can inhibit the growth of MHDI, as well as why the increase of MHDI has been related to an increase in traffic deaths in Brazil. Combatting violence in the country may represent a great advance in human development in the future and a real improvement in quality of life and wellbeing of the population.

It is important, however, to enumerate the limitations of the study. First, because the raw data were obtained from different databases, the results may be susceptible to the biases of the original sources. Second, there is no official data on suicide for the year 2010, which limited the testing of hypotheses. Third, the regression analyzes were conducted with a small sample of twenty-seven Federal Units. Due to space limitations, the method was not replicated within the numerous Brazilian municipalities, which could have generated results with greater statistical power. Fourth, the analysis also ignored other forms of violence, namely, those that do not involve death and those that target specific groups, such as women, children and adolescents, the elderly and homosexuals.

\section{CONCLUSION}

This study showed that the relationship between human development, inequality, the proportion of poor people and violence (here operationalized by rates of violent deaths) is complex and has a different dynamic according to the year (1991, 2000, 2009 and 2010). The assumption that the increase in MHDI leads to reduction of violence in the long term is not confirmed by correlation and regression analysis. On the other hand, there are indications that the decrease in homicides between 1991 and 2009 results in improved MHDI rates in 2010. This study seems to be the first in Brazil to test this relationship empirically. The method should, however, be replicated with data from municipalities, including information after the year of 2010 and other forms of violence, so that the findings can be corrected or ratified and improved.

\section{REFERENCES}

1. Gomes LF. IDH, desigualdades e homicídios. [cited 11 July 2015]. Available from: http://institutoavantebrasil.com.br/idh-desigualdades-e--homicidios/.

2. Fachin P. Mapa da Violência 2014 confirma caso de violência epidêmica no Brasil. Entrevista especial com Julio Jacobo Waselfisz. [cited 11 July 2015]. Available from: http://www.ihu.unisinos.br/ entrevistas/533141-mapa-da-violencia-2014-confirma-caso-de-violencia-epidemica-no-brasil-entrevista-especial-com-julio-jacobo-waselfisz

3. Silva JF, Oliveira TCM. Desenvolvimento humano e suas relações com a violência urbana na fronteira internacional de Mato Grosso do Sul. [cited 11 July 2015]. Available from: http://www. propp.ufms.br/gestor/ titan.php?target=openFile\&fi leld=423

4. Malik K. Human Development Report 2014: Sustaining Human Progress: Reducing Vulnerabilities and Building Resilience. New York: United Nations Development Programme; 2014.

5. Atlas do Desenvolvimento Humano no Brasil. [cited 11 July 2015]. Available from: http://www.atlasbrasil. org.br/2013/

6. Marc A, Willman AM. Violence in the City: Understanding and supporting community responses to urban violence. Washington: World Bank, 2010.

7. Waiselfisz JJ. Map of violent deaths. Estud Av. 2007; 21(61):119-38. DOI: http://dx.doi.org/10.1590/S010340142007000300009

8. Krug EG, Mercy JA, Dahlberg LL, Zwi AB. The World report on violence and health. Lancet. 2002; 360: (9339): 1083-8. DOI: http://dx.doi.org/10.1016/S0140-6736(02)11133-0

9. Wilkinson R, Pickett K, Reich RB. The spirit level: Why greater equality makes societies stronger. New York: Bloomsbury Publishing USA; 2009; p.352

10. Instituto de Pesquisa Econômica Aplicada (IPEA). Ipeadata. [cited 11t July 2015]. Available from: http:// www.ipeadata.gov.br/

11. Waiselfisz JJ. Mapa da violência 2013: homicídios e juventude no Brasil. Brasília: Secretaria Nacional de Juventude; 2013.

12. Waiselfisz JJ. Mapa da violência 2013: acidentes de trânsito e motocicletas. Rio de Janeiro: CEBELA-FLACSO; 2013.

13. Birckmayer J. How can we prevent violent behavior? [cited 11 July 2015]. Available from: http://www.neverhitachild.org/prevent.html 
This article is distributed under the terms of the Creative Commons Attribution 4.0 International License (http://creativecommons.org/licenses/by/4.0/), which permits unrestricted use, distribution, and reproduction in any medium, provided you give appropriate credit to the original author(s) and the source, provide a link to the Creative Commons license, and indicate if changes were made. The Creative Commons Public Domain Dedication waiver (http://creativecommons.org/publicdomain/zero/1.0/) applies to the data made available in this article, unless otherwise stated.

\section{Resumo}

Porque países com os maiores Índices de Desenvolvimento Humano (IDH) apresentam taxas baixas de violência, é comum supor que o aumento de IDH pode levar à diminuição das taxas de violência num país. O presente trabalho analisou a relação entre os Índices de Desenvolvimento Humano Municipal (IDHM) e mortes violentas nos estados brasileiros entre 1991 e 2010. Foi testado se o aumento de IDHM reduz indiretamente a violência ou se a redução da violência prediz maior IDHM em anos posteriores. Os dados brutos foram obtidos a partir de três fontes online, Atlasbrasil, IPEAdata e Mapa da violência. As análises não confirmam a suposição de que o aumento de IDHM leva a diminuição da violência. Mas há indícios de que a diminuição de homicídios ao longo dos anos resulta em melhores índices de IDHM em 2010. Os resultados sugerem que tomar medidas que visam desenvolvimento não implica automaticamente em redução da violência, mas combater a violência pode representar aumento de IDHM.

Palavras-chave: violência, índice de desenvolvimento humano, desigualdade, Brasil. 